Şırnak Üniversitesi

Ilahiyat Fakültesi Dergisi

Sayı 27 Aralık 2021

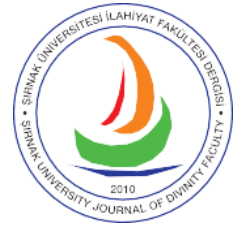

e-ISSN 2667-6575
Şırnak University

Journal of Divinity Faculty

Issue 27 December 2021

\title{
Üsâme b. Münkız'ın el-Bedi' fî Naḳdi'ş-Şi'r Adlı Eserinin Edebî Tenkit Literatüründeki Yeri ve Önemi
}

The Place and Importance of Usama Ibn Munqidh's al-Badi' fi Naqd al-Shi'r in the Literary Criticism

\section{Ali SEVDí}

Dr. Öğr. Üyesi, Iğdır Üniversitesi, İlahiyat Fakültesi, Arap Dili ve Belagatı Ana Bilim Dalı Assistant Professor, I $\breve{g} d \imath r$ University, Faculty of Divinity, Department of Arabic Language and Rhetoric Iğdır, Turkey alisevdi1984@hotmail.com https://orcid.org/0000-0002-1951-7232

\section{Makale Bilgisi / Article Information}

Makale Türü / Article Types: Araştırma Makalesi / Research Article

Geliş Tarihi / Received: 06 Ağustos / August 2021

Kabul Tarihi / Accepted: 15 Ekim / October 2021

Yayın Tarihi / Published: 15 Aralık / December 2021

Sayı / Issue: 27 Sayfa / Pages: $25-47$

Atıf / Cite as: Sevdi, Ali. "Üsâme b. Münkız'ın el-Bedi' fì Naḳdisş-Şi'r Adlı Eserinin Edebî Tenkit Literatüründeki Yeri ve Önemi [The Place and Importance of Usama Ibn Munqidh's al-Badi' fi Naqd al-Shi'r in the Literary Criticism]". Şırnak Üniversitesi Ilahiyat Fakültesi Dergisi - Şırnak University Journal of Divinity Faculty 27 (December 2021),25-47. https://doi.org/10.35415/sirnakifd.979681

Etik Beyanı / Ethics Declaration: Bu makalede bilimsel araştırma ve yayın etiği ilkelerine riayet edilmiştir. Makale etik izin gerektirmeyen bir çalışma olup en az iki hakem tarafından incelenmiş ve intihal içermediği teyit edilmiştir./ In this article, the principles of scientific research and publication ethics are respected. The article is a study that does not require ethical permission. It has been reviewed by at least two referees and was confirmed that it did not contain plagiarism.

Copyright $\odot$ Published by Şırnak Üniversitesi, İlahiyat Fakültesi / Şırnak, Türkiye (Şırnak University, Faculty of Divinity, Şırnak, 73000 Turkey). 


\section{Özet}

Hayatının büyük kısmını Abbâsilerin, son yıllarını ise Eyyûbî Devletinin kurucusu Selâhaddîn-i Eyyûbî'nin danışmanlığını yaparak geçiren, "Kılıcı ve Kalemi Keskin" unvanıyla anılan Üsâme b. Münḳız (öl. 584/1188), yaşadığı dönemin önemli edebiyatçlarından biridir. Kitâbü'l-I'tibâr, el-Menâzil ve'd-diyâr, Lubâbu'l-âdâb, Kitâbü'l-'Așâ,

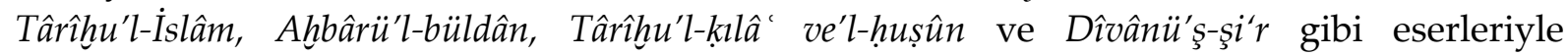
edebiyat ve tarih alanında önemli çalışmalar ortaya koymuştur. Kendi çalışmaları dışında kaynak kitaplarında çok sayıda şiiri yer alan Üsâme b. Münḳız, şiirlerinde edebî sanatlara yoğun bir şekilde yer vermiştir. Özellikle belâğat ve edebî tenkit içerikli el-Bedî ' fì nakdi'ş-şi 'r (şiir eleştirisi/edebî tenkit konusunda eşsiz/benzersiz bir kaynak) adlı eseri günümüze kadar ulaşmış, edebî tenkit ve belâğat ilmine önemli katkılarda bulunmuştur. Üsâme b. Münḳız bu eserinde, kendinden önce kaleme alınmış olan meşhûr edebî tenkit kitaplarını tarayarak onlarda dağınık şekilde bulunan bilgileri derli toplu hale getirip okuyucuya sunmayı amaçlanmıştır. Bunun yanı sıra eserde şiirin güzel yanları ve kusurlarını da ele almıştır. Bilgileri aldığı ve çalışmasına referans olarak gösterdiği bazı önemli müelliflere de işaret ettiği bu eserini doksan beş bâba ayırmıştır. Her bâbda belâğat konularına değinen müellif, hâtimede ise özellikle edebî tenkit üzerinde durmuştur. Bu eser, bedî‘ isminden de

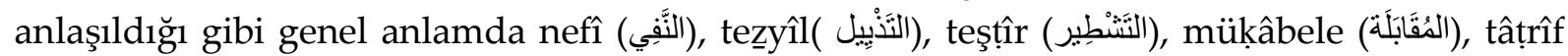

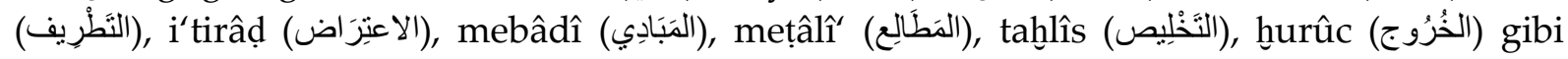
günümüz edebî tenkît ve belâğat kitaplarında pek de karşılaşılmayan, ancak üslubu güzelleştiren, ona âhenk katan ve bu alanda temel oluşturacak başlıklarla doludur. Üsâme b. Münkız eserde sadece üslubu güzelleştiren ve ona renk katan başlıklarla yetinmeyip haşv

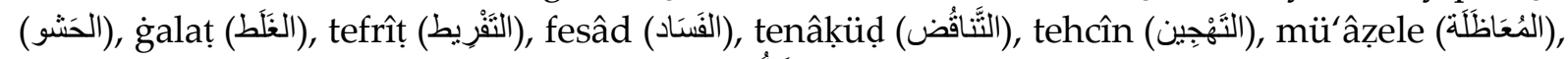

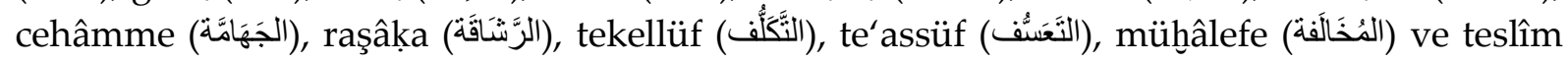
(التَّليح) gibi ifadeyi zayıflatan ve değerini düşüren konulara da değinmiştir. Bu anlamda eserde en çok göze çarpan özelliklerden birisi, üslubu güzelleştiren maddelerden sonra ifadeyi zayıflatıp çirkinleştiren maddelerin de ele alınmış olmasıdır. Bu yönüyle eserin, elBedî' fî nakdi'ş-şi 'r unvanını hak ettiğini, deyim yerindeyse ismiyle müsemma bir eser olduğu rahatlıkla söylenebilir. Müellif ele aldığı konuya bir bâb (unvan) koyduktan sonra, onu anlaşılır kolay bir üslupla tanımlayarak gerek Kur'ân, gerek hadis, gerekse çok sayıda seçkin şuarânın şiirleriyle ve füsehânın nesirleriyle konuyu açıklamaya çalışmıştır. Tarihî seyri içerisinde farklı etkenlerden dolayı zayi olup zamanımıza ulaşamayan diğer bazı eserlerdeki önemli bilgilerin bu eserde kayıt altına alınmış olması, eserin değerini artırmaktadır. Esere önem kazandıran diğer bir husus müellifin, birkaç fâsılada gerek övünen gerekse yerilen edebî çalıntılara da değinmiş olmasıdır. Bu çalışmada Üsâme b. Münḳız'in hayatı kısaca ele alındıktan sonra edebî tenkit alanında yazılmış olan birtakım eserler tanıtılmış, sonrasında ise müellifin $e l$-Bedî̀ fî̀ nakdi'ş-şi'r adlı eserinin edebî tenkîd literatüründeki yeri ve önemi üzerinde durulmuştur.

Anahtar Kelimeler: Arap Dili ve Belagatı, Edebî Tenkit, Üsâme b. Münḳız, Şiir, Belâğat, Şiir Tenkidi. 


\section{Abstract}

Usāmah Ibn Munqidh (d. 584/1188) who spent most of his life as a consultant to the Abbasids and served his last years to the founder of the Ayyubid State, Salahaddin-i Eyyubi, and is known for his "sharp sword and sharp pen" is one of the important writers of his time. He produced important works in the field of literature and history such as Dîvānü'sh-shi'r, Kitābü'l-I'tibār, al-Menāzil ve'd-diyār, Lubābu'l-ādāb, Kitābü'l-'Așā, Tārîkhu'l-Islām, Akhbārü̈lbüldān, Tārîkhu'l- qılā' ve'l- husșûn. Apart from his own works, Usāmah Ibn Munqidh, who has many poems in source books, has included literary arts in his poems densely. In particular, his work al-Bedî̀ fî̀ naqdi'sh-shi'r (a unique source on poetry/literary criticism) with the content of rhetoric and literary criticism has survived until today and has made significant contributions to the science of literary criticism and rhetoric. In this work, Usāmah Ibn Munqidh scanned the famous literary criticism books written before him and aimed to tidy up the scattered information in them and present it to the reader. In addition to this, he also discussed the beautiful aspects and flaws of poetry in the work. He divided this work into ninety-five chapters, in which he also pointed to some important authors, whom he benefited from and cited references from their works. The author, who touched upon the subjects of rhetoric in each chapter, focused on literary criticism in the epilogue. This work, as it is understood from the word bedi' contained in the work's name, generally includes

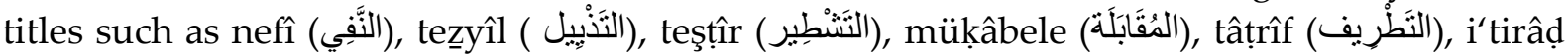

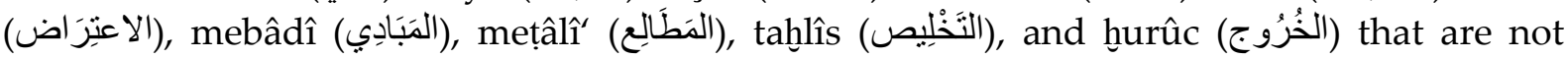
often encountered in today's literary criticism and rhetoric books, but that beautify the style, add harmony to it and form the basis of this field. Usāmah Ibn Munqidh is not satisfied with the titles that only beautify the style and enrich the text but also touched upon the issues that

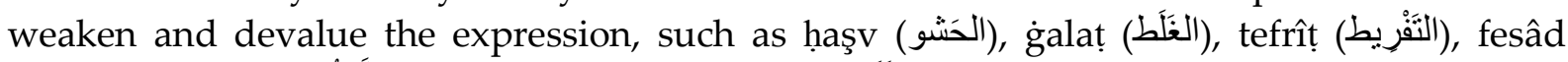

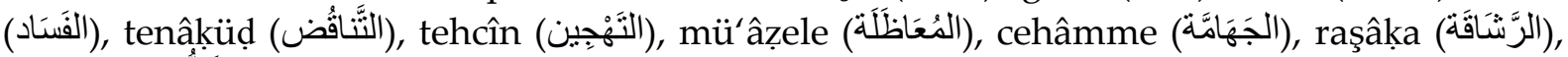

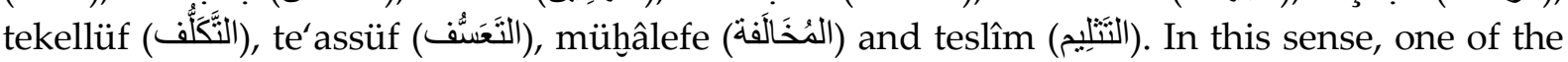
most striking features of the work is that after the items that beautify the style, the items that weaken the expression and make it ugly are also discussed. In this respect, it can easily be said that the work deserves the title of al-Bedî' fi naqdi'sh-shi'r, and that it is a work that is true to its name. After the author gave a bāb (title) to the subject he dealt with, he tried to explain the subject with the Qur'an, hadith and the poems of many distinguished poets and prose by defining it in an easy-to-understand style. The fact that important information in some other works, which were lost due to different factors in their historical course and could not reach our time, was recorded in this work increases its value. Another point that gives importance to the work is that the author also mentioned the literary steals that were both praised and criticized under a few titles. In the present study, some works written in the field of literary criticism are introduced after Usāmah Ibn Munqidh's life is briefly discussed, and then the place and importance of the author's work named al-Bedî ' fì naqdi'sh-shi' $r$ in the field of literary criticism is emphasized.

Keywords: Arabic Language and Rhetoric, Literary Criticism, Usāmah Ibn Munqidh, Poetry, Eloquence, Poetry Criticism. 


\section{Giriş}

Emeviler dönemi, başlayan ilmî kıvılcımların her yönüyle olgunlaştı̆̆ı, Arap grameri dâhil tüm ilmî disiplin faaliyetlerin kurumsallaştığ1 ve her branşta uzman ilim adamların yetiştiği dönem olarak bilinir. Abbâsî dönemi ise İslâm medeniyetinin, fikir alanında en parlak dönemi olmakla beraber Arap edebiyatının her yönüyle gelişme gösterdiği altın bir çağ olarak ön plana çıkar. ${ }^{1}$ Zira bu dönemde gerek devlet ricâlinin gerekse toplumun ileri gelenlerinin ilim ve ilim erbabını desteklemeleri neticesinde her alanda geniş bir ilmî hareketlilik müşahede edildiği gibi Arap edebiyatı tarihinde de ortaya koydukları edebî çalışmalar neticesinde ilim erbabının zihninde ve gönlünde taht kuran Ebû Muâz Beşşâr b. Bürd (öl. 167/783-84), Ebû Nüvâs (öl. 198/813), Ebu'1-Atâhiye (öl. 217/833), Ebû Temmâm etTâî (öl. 231/846), Ebû Ubâde el-Buhtürî (öl.284/897) ve Ebü't-Tayyib el-Mütenebbî (öl. 354/965) gibi birçok önemli şahsiyet ve edip yetişmiştir. Bunlardan biri de Üsâme b. Münḳı'dir.

Çalışmamız Üsâme b. Munḳız'ın zamanına dek kaleme alınmış olan edebî tenkit eserlerini kapsamakla beraber müellifin bu alanda yazmış olduğu el-Bedî̀ fînakdi'ş-şi'r adlı kitabının edebi literatürdeki konumunu ele almaktadır.

Arap âleminde ileriki sayfalarda zikredileceği gibi edebî tenkit sahasında önemli çalışmalar yapılmıştır. Türkeye' de ise edebî tenkit alanında başta M. Akif Özdoğan olmak üzere Klasik Arap Edebiyatında Edebi Tenkidin Ortaya Çıkışı, Klasik Arap Edebî Tenkidine Genel Bir Bakış, Klasik Arap Edebiyatı'nda Karşılaştırmalı Edebî Tenkidin Ortaya Çıkışı; Ahmet Bulut, Arap Edebiyatında Edebî Tenkit ve Belâgatın Tarihî Seyri; Sadık İbrahim Arcun, İlk İslâmî Dönemde Edebî Tenkîd, Hacer Gülşen, Tenkit ve Edebî Tenkit; İsa Güceyüz, Belâğat ve Edebî Tenkit Terimlerinin Teşekkülü Üzerine Bir Bibliyografya Denemesi I; Ferhat yılmaz, Arap Edebiyatında Tenkîdin Seyri gibi çalışmalar yapılmıştır. Ancak Üsame b. Münḳız ve eserleri üzerinde istenilen seviyede çalışmalar olmadığı gibi özellikle $e l$-Bedî̀ fî nakdi'ş-şi 'r adlı eserinin bu alanda önemli bir yer edinmesine binâen böyle bir çalışmanın yapılması uygun görülmüştür.

1 Hakkı Dursun Yıldız, “Abbâsîler”, Türkiye Diyanet Vakfı İslam Ansiklopedisi (İstanbul, TDV Yayınları, 1988), 1/31-48. 


\section{1. Üsâme b. Münkız'ın Hayatına Kısa Bir Bakış}

Edebiyatçılığı, üretkenliği ve yazarlığıyla dördüncü Abbâsî döneminin önemli âlimlerinden sayılan Üsâme b. Münkız, yaklaşık 488/1095 tarihinde Hamâ'nın kuzey batısındaki Şeyzer' de doğdu. ${ }^{2}$

Benî Münkız ismiyle bilinen, ilim-irfân ve cesaretiyle tanınan asil ve bilge bir aileden gelen Üsâme b. Münkız, bir edebiyatçı olan pederi ve güçlü bir siyasetçi olan amcası tarafından, ileride emîr olacağı düşüncesiyle çok yönlü olarak yetiştirilmiştir. ${ }^{3}$ İlk olarak küçük yaştan itibaren okuma yazmayı öğrenip bunu Allah'ın kelāmını hıfzetmekle süslendikten sonra, Arapça olan İslâm dininin temel kaynaklarını sağlam ve doğru anlayabilmenin en önemli yolu olan Arap dili grameri ve edebiyatı yanı sıra, fıkıh, tefsîr ve hadis gibi İslâm vahyinin etkisiyle ortaya çıkmış olan farklı dallarda da dersler almaya gayret etti. Bu gibi dallardan derinleştikten sonra diplomasi, genel tarih, coğrafya, hitabet ve savaş sanatına yoğunlaşarak bir şehzadenin alması gereken kültürü edinmeye çalıştı. Askerî zekâsı ve cesareti, dönemin en meşhûr komutan ve hükümdarların taktik ve siyaset gibi toplantılara kabul edilmesini sağlarken; şairliği, hitabeti ve tecrübesi ise onu edebiyatçıların ve bilginlerin kıblesi yapıyordu. ${ }^{4}$

Üsâme b. Münḳıı'ın, mümtâz edebî ve ilmî bir ortamda yetişmiş olması onun entelektüel yaşamının oluşmasında başrol oynamıştır. Ayrıca Trablus Dârü'l-'İlmi'nin başkanı ve dönemin Sîbeveyhi'si olarak da bilinen Ebû Abdullah et-Tuleytılî (öl. ?) başta olmak üzere Ebü’l-Kâsım İbn Asâkir (öl. 571/1176), Abdülkerîm b. Muhammed es-Sem’ânî

2 Ebû Abdillâh Şihâbüddîn Yâkūt b. Abdillâh el-Hamevî el-Bağdâdî er-Rûmî, Mu 'cemü'l-üdebâ', thk. Hasân Abbâs (Beyrut: Dâru'l-Ğarbi'l-İslâmî, 1993), 2/571-572; Ebu'l-Abbâs Şemsuddîn Ahmed b. Muhammed b. Hallikân el-İrbilî, Vefeyâtu'l-a'yân ve enbâu ebnâi'z-zamân, thk. İhsân Abbâs (Beyrut: Dâru Sadır, 1978), 1/195196; Ebu's-Safâ Selâhuddîn Halil b. İzziddîn Aybeg b. Abdillâh es-Safedî, el-Vâfì bi'l-vefeyât, thk. Ahmed elArnâvûd; Tûkî Mustafâ (Beyrut: Dâru İhyâi't-Turâsi'l-Arabî, 2000), 8/245; İbnu'l-'İmâd Ebu'l-Felâh Abdulhayy b. Ahmed b. Muhammed es-Sâlibî el-Hanbelî ed-Dımeşkî, Şežerâtü'ż-żeheb, thk. Abdulkâdir elArnâvud - Mahmûd el-Arnâvud (Beyrut: Dâru İbn Kesîr, 1988), 6/459; Ebû Kays Muhammed Hayruddîn b. Muhammed b. Ali b. Fâris ez-Ziriklî ed-Dımeşkî, el-A'lâm (Beyrut: Dâru 'İlmi li'l-Melâyîn, 1984), 1/291; Ebû Muhammed Abdullâh b. Esâd b. Ali b. Süleymân el-Yâfiî el-Yemenî, Mir'âtü'l-cenân ve 'ibretü'l-yakzân (Beyrut: Dâru Kutubi'l-1̂lmiyye, 1997), 3/323-324; Ebü'l-Haris Müeyyidüddevle Necmüddîn Üsame b. Mürşid b. All b. Muḳalled b. Nasr b. Münḳız eş-Şeyzerî el-Kinanî el-Kelbî, el-Bedi' fì nakdi'ş-şi'r, thk. Ahmed Ahmed Bedevî Hâmid Abdulmecîd (Kahire: 1960 - Beyrut: y.y. 1987), 1-5; a.mlf., Lübâbü'l-âdâb, thk. Ahmed Muhammed Şâkir (Kahire: Mektebetü's-Sünne, 1987), 16; a.mlf., Dîvânü'ş-şi'r, thk. Ahmed Muhammed Bedevî - Hâmid Abdülmecîd (Kahire: Âlemü'l-Kutub, 1983), 5; Ali Sevim, “İbn Münḳı”", Diyanet İslam Ansiklopedisi (İstanbul: TDV Yayınları, 1999), 20/ 221-222.

3 Benû Münḳız kabilesi hakkında detaylı bilgi için bk. Üsâme b Münḳız, el-ít'ibâr, thk. Abdulkerîm el-Eşter (Beyrut: Mektebetü'l-İslâmiyye, 2003), 11-14; Abdulkerim Özaydın “Münḳı/Benî Münḳı”, Diyanet İslam Ansiklopedisi (İstanbul: TDV Yayınları, 2006), 32 /15-16.

4 İbn Münḳı, Lübâbü'l-âdâb (mukaddime), 16-21; a.mlf., el-İtibâr, 6; Sevim, “İbn Münḳ1z”, 20/221-222. 
(öl. 562/1166) ve hadisçi Ebü'l-Hasan Ali b. Sâlim es-Senbesî (öl. h. 499) gibi dönemin birçok ve farklı yönlü meşhûr âlimleri ile karşılaşmış olması ve onlardan ilim tahsil etmesi, onun iyi yetişmesinde ve şahsiyetinin oluşmasında etkisi olduğu muhakkaktır. ${ }^{5}$

Yaşamış olduğu asrın ilmî ve kültürel çevreyi iyi bir şekilde değerlendiren Üsâme b. Münkız, çok yönlü ve üretkenliğiyle özellikle edebiyat ve tarih alanında kendisinden sonra İslâmî ilimlerle meşgul olanların faydalanacağı önemli eserler kaleme alarak büyük bir ilmî servet bırakmıştır. Fakat şu bir gerçek ki, birçok ilk dönem âlimlerinde de görüldüğü gibi, Üsâme b. Münkız'in de kaynaklarda bahsi geçiyor olmasına rağmen eserlerinin pek çoğu zaman içerisinde kaybolmuş ve maalesef ancak bir kısmı günümüze kadar gelebilmiştir.

Üsâme b. Münkız, eserlerinin birçoğunun günümüze ulaşamamanın gerekçesini ise, bir saldırı esnasında Haçlılar tarafından çalındığını ve hayatında onu en çok üzen ve derinden etkileyen olaylarından bir olduğunu; onun acısını ömrü boyunca kalbinden

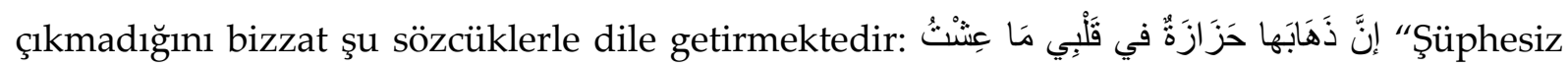
onların gidişi yaşadığım sürece kalbimde bir acı /sızı olarak kaldı." ${ }^{6}$ el-I'tibâr, el-Menâzil ve'dDiyâr, Lubâbu'l-Âdâb, Dîvânü'ş-şi'r, el-'Asâ, Telhîsü̈l-menâkıbi'l-'Ömereyn li'bni'l-Cevzî̀ ve konumuzun ana eksenini oluşturan el-Bedi' fî nakdi'ş-şi'r adlı eseri günümüze ulaşan eserleridir.

Üsâme b. Münkız, cesareti, kahramanlığı ve ilmî kişiliğiyle İslâm ülemâsının ilgisini çektiği gibi, özellikle kendisini keşfettikten sonra yaklaşık ömrünün yarısını eserlerini Fıransızca'ya tercüme etmeye adayan Fransız müşteşrik Hartwig Derenbourg (öl. 1844-1908) ile birlikte müsteşriklerin de ilgi odağında yer edinmiş bir kişiliktir. Hülasa, ilmi kişiliği ve Haçlı seferlerindeki kahramanlığı kılıcı ve kalemi keskin unvanıyla anılmasının yanı sıra bir deprem sırasında hemen hemen bütün ailesini kaybetmesi ve malum olayda emek mahsulü, göz nuru eserlerinin çalınması gibi etkenlerden dolayı mahzun şâir ve bilge olarak da bilinen Üsâme b. Münkız, yaklaşık 93 yaşındayken 584/1188 yılında Dımışk'ta/Şam'da vefat etmiştir.7

5 İbn Münḳız, Lübâbü'l-âdâb (mukaddime), 21; Ferrânî, el-Ḳıymetu'l-ilmiyye li rivâyât İbn Münḳı eş-Şefeviyye fî Kitâbi'l-I'tibâr (Gazze: Yüksek Lisans Tezi, ts. ), 361; Sevim, “ïbn Münḳı””, 20/ 221-222.

6 İbn Münḳ1z, el-i'tibâr, 78.

7 İbn Hallikân, Vefeyâtu'l-a'yân, 1/199; Yâkût el- Ḥamevî, Mu'cemu'l-üdebâ', 2/572; Safedî, el-Vâfí bi'l-vefeyât, 8/245; İbnu'l-'İmâd, Şezerâtü'z-žeheb, 6/460; Ziriklî, el-A'lâm, 1/291; Zehebî, Hâfız, el- '̇̉er fî haberi men ġaber, 3/87-88; Yâfiî, Mir'âtu'l-cennân, 3/323-324; İbn Münḳız, Lübâbü'l-âdâb (mukaddime), 21; a.mlf., Dîvânü'ş-şi'r (mukaddime), 5-10. Sevim, “ỉbn Münḳız”, 20/ 221-222. 


\section{2. Şiir ve Şiir Tenkidi ile Edebî Tenkit Alanında Yazılmış Bazı Önemli Eserler}

Sözlükte الثِِْرُ (şiir), “bir şeyi inceliklerini kavrayarak bilmek, sezerek vâkıf olmak;

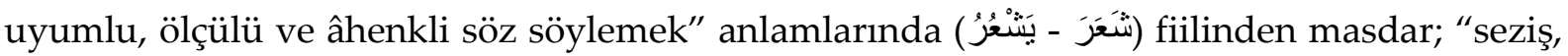
hissediş, sezgiye dayanan bilgi; duygu ve heyecandan kaynaklanan uyumlu, ölçülü ve âhenkli söz" mânasında isimdir. ${ }^{8}$ En eski edebiyat türlerinden biri olan şiir, farklı sanat anlayışlarına bağlı olarak çeşitli tarifleri yapılmış, onun tanımlanamayacağı da ileri sürülmüştür. Yine de genelde şiirin, kendine has dili ve ifade ediliş özelliğiyle duygu, düşünce ve hayalleri belli bir düzen içinde ve ahenkli mısralara bağlı olarak aktaran yaratıcı bir söz sanatı olduğu noktasında birleştiği söylenebilir.

Edebî türlerin en eskisi ve özel bir anlatım diline sahip olan şiir, insanlık tarihi boyunca duygu, düşünce ve hayalleri etkili biçimde anlatmanın bir yolu; edebî melekenin eğiticisi ve sanatsal yeteneğinin geliştiricisi olmuştur. ${ }^{9}$ Şiir sanatı ve literatürü, her toplumun tecrübe birikimini hem de toplum hayatının farklı biçimlerini betimleyen bir edebî tür olarak diğer edebi türlere göre bir dildeki edebî ürünlerin en üst örneklerinden olmuştur. Bu anlamda reel olarak bakıldığında bütün dillerde ve kültürlerde şiir, önemli bir edebî sanat olarak yer edinirken; özelde ise Arap edebiyatında, içtimaî hayat ve kültüründe şiir ve şâirin çok büyük ve hayatî etkisi olmuş dolayısıyla; şiir ve şâir toplumda aynı derecede önemli bir yer edinmiştir. Bu anlamda şiir, toplumun his dünyasını aksettiği için yüzyıllar boyunca yazılmadan, ezberlenerek hafızalarda yaşatmıştır. ${ }^{10}$

Şâirler, mensûp olduğu toplumun âlimi, tarihçisi, koruyucusu olup, toplum bireyleri arasında herkesin üstünde bir itibara sahip iken, şiir de özellikle İslâm öncesi süreçte Arap toplumun estetik duygu, dil ve zevk bakımından büyük bir ilerlemeye ulaşmasına da katkı sağlamıştır. Nitekim Arap dili, târihî, sosyo-kültürel ve dinî yaşayışı gibi bilgilerin azımsanmayacak yekunu şiir vasıtasıyla elde edilmiştir. Öte yandan özellikle eski Arap şiiri Kitâbu'l-İbil, Kitâbu'l-Haşerât, Kitâbu'n-Nebât gibi sistematik dil kitaplarının, gramer

8 Ebü'l-Fazl Cemâlüddîn Muhammed b. Mükerrem b. Alî b. Ahmed el-Ensârî er-Rüveyfiî, Lisânu'l-'Arab (Beyrut: Dâru Sâdır, 1414), 4/409; Ebü't-Tâhir Mecdüddîn Muhammed b. Ya'kūb b. Muhammed el-Fîrûzâbâdî, el-Kāmûsü'l-muhît (Beyrut: Müessisetü'r-Risale Li't-Tiba' ve'n-Neşr, 2005), 533; Ebü'l-Abbâs Hatîbüddehşe Ahmed b. Muhammed b. Alî el-Feyyûmî el-Hamevî, el-Miṣbâhu'l-münîr fî garâibi'ş-şerhi'l-kebîr li'r-Râfi 'î (Kahire: y.y. 1901), 1/152; Rahmi Er, “Tenkit”, Türkiye Diyanet Vakfi İslam Ansiklopedisi (İstanbul: TDV Yayınları, 2021), 40/458-461.

9 İsmail Ekinci, “Arap Şiiri Ansiklopedisi Programı (el-Mevsû'atu'ş-Şi ‘riyye)”, Marife Dini Araştırmalar Dergisi 19/2 (Kasım: 2019), 768-769.

10 Nihat M. Çetin, Eski Arap Şiiri (İstanbul: Edebiyat Fakültesi Yayınları, 1973), 9-10. 
kurallarının ve daha sonra telif edilen pek çok ansiklopedik eserin de başlıca kaynağını oluşturmuştur. Bu itibarla şiir Arapların kültür hazinesi, divânı ( Dîvânu'l-'Arab), yani Arapların bütün bilgilerini içine alan, bunların muhafazasını temin eden, daima başvurulan ve kendisinde istifade edilen temel kaynak olarak nitelendirilir. ${ }^{11}$ Kur'ân-1 Kerîm'in içerdiği kelimelerinin Arapça oluşunu ispat etme teşebbüsünün yanı sıra dil ve gramerle ilişkili İslâmî disiplinler veya konular eski Arap şiiri / câhiliye dönemine nispet edilen şiirlerle irtibatlandırılmakta, özellikle tefsirde hemen hemen en önemli dil malzemesi olarak eski Arap şiiri görülmektedir. ${ }^{12}$ Nitekim İbn Abbâs (öl. 68/687) bu durumu şu şekilde ifade etmiştir: “Allah'ın kelâmından bir şeyler okuyup anlamadığınız zaman, onu Arapların şiirlerinde arayınız! Çünkü şiir, Arapların divanıdır." ${ }^{13}$ Verilen bilgiler ışı̆̆ında bakıldığında kelâmullâh ve hadisi şerifin dil inceliklerini anlamak, lügat ve gramer güçlüklerini açılamak gibi hususların önemli temel taşlarından birini oluşturması nedeniyle eski şiirden faydalanıldığ ${ }_{1}$ kaynaklardan açıkça anlaşılmaktadır. ${ }^{14}$ Bu anlamda Arap şiiri, İslâmî ilimler açısında hayatî bir öneme sahip olduğu; İslâmî disiplinlerde olmazsa olmaz temel kaynaklardan olduğu rahatlıkla söylenebilir.

Arap şiirinin, Arapçanın birçok bilim dalının ortaya çıkması ve gelişmesine katkı sağlayıp kurucu unsur olmasının yanı sıra, araştırmacıların söz konusu ilimlerin tespit ve tedrisatında duyduğu malzeme ve kanıtları (şâhid) kendilerine sağlaması gibi özellikleri ihtiva ettiğinden, daha sonra gerek eleştirmenler gerek belâgat âlimlerin ihtimamını celp etmiş, kendisi bizzat araştırma, analiz ve eleştiri konusu olmuştur. Nitekim şiirin bu gibi özellikleri şiir tenkidi (naḳdu'ş-şi'r) gibi bir sanatın doğmasına vesile olmuştur. Fakat klasik ülemâ ve üdebânın şiir tenkidi veya tenkid ilmi (ilm-i naḳd) adını verdikleri bu edebî tür, târihî süreçte daha çok edebî tenkit başlığı altında ele alınmıştır. ${ }^{15}$ Genel anlamıyla edebiyatın önemli bir kolu sayılan edebî tenkit ister şiir ister nesir olsun, bu meyanda

11 Ebû Abdillâh Muhammed b. Sellâm el-Cumahî el-Basrî, Țabakātü fuĥ̂li'ş-şu 'arâ', nşr. M. M. Şâkir (Kahire: y.y. 1953), 1/24: Ebû Hilâl el-Hasen b. Abdillâh el-Askerî, Kitâbü'ṣ-Șinâ'ateyn (Kahire: Dâru Fikri'l-Arabiyye, 1971.), 1/138-139; Ebû Tayyib el-Luğavî, Merâtibü'n-nahviyyîn, nşr. Ebu'l-Fadl İbrahim (Kahire: Dâru'l-Maârif, 1984), 1/11-12; Corcî b. Habîb Zeydân, Târîhu âdâbi'l-luğati'l- 'Arabiyye (Kahire: Dâru'l-Hilâl, ts.), 1/58-59; Ömer Abdirrahmân b. Ömer Ferrûh, Târîhu'l-edebi'l- 'Arabî (Beyrut: Dâru'l-İlm li'l-Melâyîn, 1981), 1/ 73.

12 Corcî Zeydân, Târîhu âdâbi'l-lug̉ati'l- 'Arabiyye, 1/ 195; 2/ 14-15.

13 Ebû Alî el-Hasen b. Reşîk el-Ezdî el-Kayrevânî, el- 'Umde fî̀ mehâsini'ş-şi 'r ve âdâbih (Beyrut: Dâru'1-Cîl, 1981), 1/ 30.

14 Nihat M. Çetin, “Arap (Edebiyat)”, Türkiye Diyanet Vakfi İslam Ansiklopedisi (İstanbul: TDV Yayınları, 1991), 3/276-309.

15 Tâhiru'l-Mevlevî, Edebiyat Lügati, Yay. Haz. Kemâl Edip Kürkçüoğlu (İstanbul: Enderun Kitapevi, 1973), 164165. 
yazılmış eserlerin değerini ortaya koymak amacıyla, zayıf- güçlü veya iyi- kötü yönlerini belirlenmiş ölçütlere göre analiz edip ortaya koyan edebî bir sanattır. Daha açık bir ifadeyle; bir edebî çalışmanın hangi nedenlerden ötürü ve ne dereceye kadar kötü ya da iyi olduğuna yönelik karar verme sanatıdır. Arap edebiyatında edebî eserlerin hem form /şekil, hem de yap1 yönüyle ilgilenen; güzelliklerinin, gerçekliğinin, yeniliğinin, üslûbunun, felsefesinin ortaya çıkarılmasını sağlaması gibi özellikleriyle yaratıcı bir yanı bulunan bu edebî tür, başlangıçta "belâgat"ın bir alt başlığı olarak görülmüş ise de belli zamandan sonra bağımsız

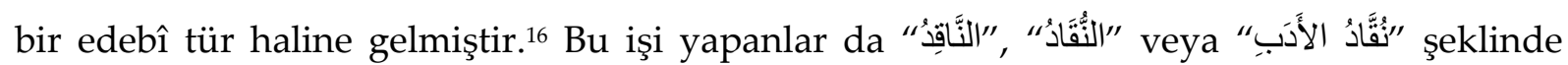
isimlendirilmişlerdir.

Câhiliye döneminde daha yalın ve basit bir şekilde yürütülen edebî tenkit, edebî haz ve estetik bağlamında şiir ve şairlerle ilgili yapılan değerlendirmelerden ibaretti. İslâmî dönemde ise; belagat, nazm ve diğer tüm edebî sanatlar yönünde benzeri bir metin getirmeleri hususunda Kur'ân'ın inkârcılara meydan okuması edebiyata ciddi bir etki yaparak bu alanda tarihi bir değişime neden olup edebi eleştiriye de yeni bir yön kazandırmıştır. Bu yönün gelişiminde Hz. Peygamber'in sahip olduğu dil hassasiyeti ve edebî zevkin de ciddi bir etkisi olmuştur. Emeviler döneminden itibaren edebiyatın teşvik edilmesi ve edebiyatçılara birtakım imtiyazların tanınması edebî tenkidin gelişiminde etkin olmuştur. Abbâsîler döneminde ise medenî ve fikri ilerlemeyle birlikte doğal yapısından çıkıp bilimsel bir hüviyete bürünen edebî tenkidin kuramsal kuralları belirlenmiş ve bu alanda çok sayıda eser kaleme alınmıştır. Belagat kavramları ve şiir sirkati/intihali konuları da bu dönemde edebî eleştiri çerçevesinde değerlendirilmiştir. ${ }^{17}$

\subsection{Edebî Tenkit Alanında Yazılmış Bazı Önemli Eserler}

Daha önceki satırlardan belirtildiği üzere şiirin ehemmiyetine binâen bağımsız bir edebî tür olarak bizzat ülemâ ve üdebânın ilgi odağı olmuş, şiir ve şiir tenkidi hakkında birçok araştırma, ilmî çalışma yapılmış ve ciddi oranda eser kaleme alınmıştır. Bazısı içerik olarak daha çok şiir tenkidi, dolayısıyla şiir ve şiirin ne olduğu hakkında iken bazısı ise belâgat nitelikli eserler olup şiir sanatının meânî, beyân ve bedî ‘ ilim dalları için zengin bir

16 Kenan Demirayak, Arap İslam Edebiyatı Literatür Bilgisi (İstanbul: Cantaş Yayınları, 2016), 142-143; İsa Güceyüz, "Belâgat ve Edebî Tenkit Terimlerinin Teşekkülü Üzerine Bir Bibliyografya Denemesi I", Hitit Üniversitesi İlahiyat Fakültesi Dergisi 19/1 (Haziran 2020), 481.

17 M. Akif Özdoğan, "Klasik Arap Edebî Tenkidine Genel Bir Bakış” Kahramanmaraş Sütçü İmam Üniversitesi Sosyal Bilimler Dergisi 12/ 1 (2015), 25. 
madde ve kaynak içermesinden dolayı belâgat ve şiir tenkidi iç içe işlenmiştir. Bu anlamda Arap edebiyatında "sözün, fasih olmakla beraber yer ve zamana da uygun olması" anlamına gelen belâgat öncelikle edebî tenkit şeklinde başlamış, İslâmî dönemde ise Kelamullah'ın icazı üzerindeki çalışmalar hem de edebî tenkit nedeniyle süratli bir şekilde devam etmiştir. Bu itibarla belâgat ile edebî tenkit 4/10. yüzyıl sonlarına kadar birlikte işlenmiş; ancak h. 4 . asırdan itibaren belâgat edebî tenkitten ayrılarak bağımsız bir edebî alan haline gelmeye başlamıştır. Dolayısıyla belâğatın temeli, edebî tenkide dayandığı söylenebilir. Bu anlamda edebî tenkit ve belâgat konularını ele alan eserleri birbirinden tam olarak ayırmak oldukça zordur. $^{18}$

Bununla birlikte bu tür eserler, içerikleri açısında kesin olmamakla beraber bir tasnif ve ayırıma tabi tutulmuştur. Meselâ; Arstoteles'in (m.öl. 384/322) Fennu'ş-şi'r'i, el-Asma'î'nin (öl. 216/831) Kitâbu fuhuleti'ş-şu'arâ'sı, Ebü'l-Abbâs Sa'leb'in (öl. 291/903) Kav'idu'ş-şi'r'i, İbn Tabâtabâ (öl. 322/933) Iyâru'ş-ş'ir'i, Ebü'l-Ferec Kudâme b. Ca'fer'in (öl. 337/948) Nakdu'şşi' $r^{\prime} i$, Ebü'l-Hasan el-Kâdî el-Curcânî'nin (öl. 392/1002) el-Vesâtạ'sl, Ebû Hilâl el-Askerî'nin (öl. 395/1004) Kitâbü'ṣ-Ṣinâ'ateyn'i, İbn Reşîk el-Kayrevanî’nin (öl. 456/1063) el-‘Umde'si ve Üsâme b. Münḳız'in el-Bedi' fi naḳdi'ş-şi'r vd. eserler daha çok edebî tenkîd içerikli çalışmalardır. Ebü'l-Abbâs el-Müberred'in (öl. 286/900) el-Belâğg's1, İbnu'l-Mu'tezz'in (öl.

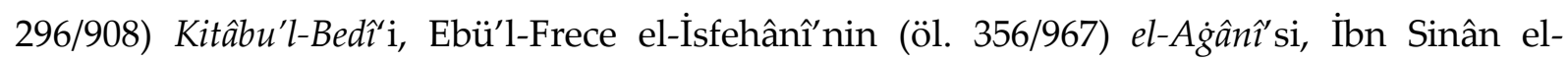
Hafâcî'nin (öl. 466/1073) ) Sırrü'l-feșâhạ'sı, Abdulkâhir el-Curcânî'nin (öl. 471/1078) Delâilu'l$i^{\prime} c_{a} z^{\prime} 1$ gibi eserler ise genel anlamıla edebî tenkit ve belâğat hakkında kaleme alınmış önemli eserlerdir. ${ }^{19}$ Konumuzun daha iyi anlaşılması bağlamında gerek edebî tenkit gerekse edebî tenkit ve belağat içerikli bazı önemli eserleri kısaca şu şekilde zikredebiliriz:

\subsubsection{Kitâbu fuhûhleti'ş-şu'arâ}

Basra dil mektebinin önde gelen simalarından, özellikle şiir sanatında uzman oluşu ile bilinen Ebû Saîd el-Asmaî (öl. 216/831) tarafından kaleme alınmış olup şâirler ve şiirleri hakkında görüş ve hükümler ihtiva eden eserlerin en eskisi sayılmaktadır. Eser, hacim bakımından küçük bir risâle ve konular yüzeysel bir şekilde işlemesine rağmen Arap

18 Demirayak, Arap-İslam Edebiyatı, 144-145.

19 Bk. Türkiye Diyanet Vakfı İslam Ansiklopedisi (söz konusu maddeler); Demirayak, Arap-İslam Edebiyatı, 142-168; Güceyüz, "Belâgat ve Edebî Tenkit Terimlerinin Teşekkülü Üzerine Bir Bibliyografya Denemesi I", 481-506. 
edebiyatında edebî tenkit ilminin gelişmesinde önemli bir basamak teşkil edecek kaynaklardandır. ${ }^{20}$

\subsection{2. Ḳavâ'idu'ş-şi'r}

Kûfe dil ekolünün önemli temsilcilerinden Ebu'l-Abbâs Sa'leb tarafından telif edilen bir şiir tenkit kitabıdır. Yöntemleri farklı olmakla beraber üçüncü asırda telif edilen İbn Kuteybe'nin (öl. 276/889) eş-Şi'r ve şu'arâ'sından sonra şiir ve şiir tenkidi alanında yazılmış en önemli eserlerden biri sayılmaktadır. Fakat eserde izlenen yöntem daha çok Kudâme b. Ca'fer'in Nakdu'ş-şi'r adlı eserine yakın olup aynı kaynaklardan etkilenmiş olmalılar ki aralarında büyük bir benzerlik görülmektedir. ${ }^{21}$

\subsubsection{Kitâbu'l-Bedî‘}

Şâir halife İbnu'l-Mu'tezz tarafında kaleme alının bu eser, Arap retoriğine ve edebî sanatlara yönelik kaleme alınmış ilk bağımsız eser olarak yâd edilmesinden edebî tenkit ve belâğat alanında mümtâz bir yere sahiptir. Eser içeriğiyle gerek edebî tenkit, gerekse belâğat ilmi ilgili daha sonraki çalışmaların temel hareket noktası olmuştur. Kitâbu'l-Bedî‘ kadim ve yeni şâirlerin sanat açısından mukayeseli olarak bir değerlendirmesi yapılarak belâgat, beyân ve ağırlıklı olarak bedî‘ mevzularının derli toplu olarak ilk defa sistemli olarak tertip edildiği bir çalışmadır. ${ }^{22}$

\subsubsection{Naḳdu'ş-şi'r $r$}

Ebü'l-Ferec Kudâme b. Ca'fer tarafından ele alınan bu kitap, nakdü'ş-şiir hakkındadır. Müellif eserinde, çeşitli teknik terimler üretip Arap şiiri tenkit sahasında yeni bir sistem, metot ve farklı bir bakış sergilemesinden dolayı eser daha sonraki hemen hemen bütün çalışmalara kaynaklık etmiştir. Belâğî bir eğilimin hâkim olduğu eserde şiir ile ilgili

20 Ebû Saîd Abdülmelik b. Kureyb el-Asmaî, Kitâbu fuhûleti'ş-şu'arâ, thk. Charles C. Torrey, Yay. Haz. Selâhuddîn el-Müncid (Beyrut: Dâru'l-Kutub'il-Cedîd, 1980); Kenan Demirayak- M. Sadi Çöğenli, Arap Edebiyatında Kaynaklar (Erzurum: Atatürk Üni. Fen Edebiyat Fakültesi Yayınları, 2000), 79-80; Demirayak, Arap-İslam Edebiyatı, 158.

21 Muhammed Zahûl Selâm, Târihu'n-nakdi'l-edebî hattâ karni'r-râbi'l-hicrî, 147.

22 Ebü'l-Abbâs Abdullāh b. Muhammed el-Mu'tezz-Billâh b. Ca'fer el-Mütevekkil-Alellah el-Abbâsî, Kitâbu'lBedî̀, thk. İrfân Matracî (Beyrut: Müessisetü'l-Kütübi's-Saḳâfiyye, 2012); İsmail Durmuş, “İbnu'l-Mu'tez”, Türkiye Diyanet Vakfi İslam Ansiklopedisi (İstanbul: TDV Yayınları, 2000), 21/143-147; Demirayak, Arap-İslam Edebiyatı, 146; Ali Bulut, Belâgat (İstanbul: M. Ü. İlahiyat Fakültesi Yayınları, 2015), 22-23. 
birçok edebî ve eleştiri teorileri incelendiği gibi bir insicâm içerisinde o devirde henüz bağımsızlığını kazanamamış olan retorik/belâgat ilmine dair mevzular da ele alınmıştır. ${ }^{23}$

\subsubsection{Kitâbü'ṣ-Ṣınâ'ateyn}

Ebu Hilâl el-Askerî tarafından telif edilen bu eser, nesir ve nazım sanatının usûl ve kaideleri hakkında yazılmış olup, edebiyatçılar tarafından intizamlı olarak yazılan ilk belâgat kitabı olarak kabul edilmektedir. Zira gerek bâb ve konuların dağılımı gerekse bunların bir insicâm içerisinde işlenişi gibi özellikleriyle eser, sistematik bir kitap olma özelliğini kazanmaktadır. Ebû Osmân el-Câhız (öl. 255/869) başta olmak üzere diğer yazarların da belâgat ve edebî tenkit hakkındaki düşünce ve saptamalarını ele alıp değerlendiren ve özgün bazı yenilikler ilave eden yazar, çalışmasını başlıca on bölüme ayırmış olup her iki dala yönelik sanatlar incelemiştir. ${ }^{24}$

\subsection{6. el-'Umde}

Ebû Ali el-Hasan İbn Reşîk el-Kayrevanî tarafından ele alınan el- 'Umde fî mehâssini'şşi'r ve âdâbih adlı eser, edebî sanatlar ve bilhassa şiir tenkidine ait olup orijinal ve özgün özellikleriyle edebî tenkit ve belâğat alanına değer katan bir çalışmadır. Özellikle Endülüs ve Kuzey Afrika belâğatçılarına yön veren eserin göze çarpan en önemli özelliği, zamanımıza kadar ulaşan ve ulaşamayan edebiyat tenkidine ve retorik ilmine dair eserlerin içeriklerini, özünü aktarmış olması; gelişim seyirleri içerisinde edebî kavramların uğradıkları değişiklikleri sunması ve belâğatçılara göre elde ettikleri farklı isimleri göstermiş olmasıdır. ${ }^{25}$

\section{3. Üsâme b. Münḳı'in el-Bedi' fî naḳdi'ş-şi'r Adlı Eserin Edebî Tenkit}

\section{Literatüründeki Yeri ve Önemi}

Üsâme b. Münḳız dönemine gelene kadar edebî tenkit sahasında önemli âlimler yetişmiş buna paralel olarak kaynak oluşturacak çok değerli eserler telif edilmiş, dolayısıyla zengin bir literatür oluşmuştur. Ebû Ubeyde Ma'mer b. el-Müsennâ'nın (öl. 209/824) Mecâzü'l-Kur 'ân'1, Ebû Osmân el-Câhiz'in (öl. 255/869) el-Beyân ve't-tebyîn'i, Ebü'l-Abbâs el-

23 Ebü'l-Ferec Kudâme b. Ca'fer b. Kudâme el-Bağdâdî, Naḳdü'ş-şi 'r, thk. Muhammed Abdülmün'im Hafâcî (Beyrut: Dâru'l-Kutubi'l-İlmiyye, ts.); Cengiz Kallek, "Kudâme b. Ca'fer" Türkiye Diyanet Vakfi İslam Ansiklopedisi (Ankara: TDV Yayınları, 2002), 311-312; Demirayak, Arap-İslam Edebiyatı, 161.

24 Ebû Hilâl el-Hasen b. Abdillâh el-Askerî, Kitâbü'ṣ-Ṣnâ'ateyn, thk. Ali Muhammed el-Becâvî - Muhammed Ebü'l-Fazl İbrahim (Kahire: Dâru'l-Fikri'l-Arabî, ts.); Ahmet Turan Aslan, "el-Askerî, Ebû Hilâl”, Türkiye Diyanet Vakfi İslam Ansiklopedisi (İstanbul: TDV Yayınları, 2991), 489-490.

25 Ebû Alî el-Hasen b. Reşîk el-Ezdî el-Kayrevânî, el- 'Umde fì mehâsini'ş-şi'r ve âdâbih. thk. Abdulvahid Şalan (Kahire: Mektebetu'l- Hanci, 2000). 
Müberred'in (öl. 286/900) el-Kâmil fi'l-edeb'i, Kudâme b. Ca'fer'in Naḳdu'ş-şi'r'i, el-Askerî'nin Kitâbü'ṣ-Ṣınâ'ateyn'i, Ebü'l-Kāsım el-Âmidî'nin (öl. 371/981) Kitâbü'l-Muvâzene beyne'țTâ'iyyeyn'i (el-Muvâzene beyne Ebî Temmâm ve'l-Buhtürî), Ebü'l-Hasan el-Kâdî el-Cürcânî'nin el-Vesâta'sı, İbn Sinân el-Hafâcî'nin Sırrü'l-fesâha's1, Ebu'l-Kâsim et-Tenûhî'nin, el-Akssa'l- karî̉b fî̀'ilmi'l-beyân'i, Ebû Ali el-Hâtimî'nin Hilyetu'l-muhâdara'sı ve Abdulkâhir el-Cürcânî'nin Delâilu'l-i'câz'1 gibi eserler o dönem revaçta olan belâğî yönü ağır basan edebî tenkit alanında yazılmış eserlerdir. Bilhassa bu dönemde, tefekküre dayalı güçlü bir tenkit ve edebî bir kişiliğe sahip olan Abdulkâhir el-Cürcânî' den sonra Arap edebiyatında “Edebiyat ve Kelâm Ekolleri” Mısır, Şam ve Irak'ta ortaya çıkmıştır. Arap edebî zevkine sahip, felsefe ve mantık kurallarına karşı mesafeli davranan ediplerin oluşturduğu bu ekolun mensupları, edebî tenkit ve belâgatı, edebî kurallar içinde ele almışlardır. Bu ekolün müntesipleri, konuların izahında âyet, şiir ve Arap atasözlerine geniş olarak yer vermişlerdir. Bu ekolün en önemli temsilcileri İbn Sinân el-Hafâcî, İbnu'l-Esîr (öl. 630/1233), İbn el-İsba' el-Misrî (öl. 654/1256), et-Tûfî el-Bağdâdî (öl. 716/1316) ve Usâma b. Münkız'dir." ${ }^{26}$ Dolayısıyla hicri üçüncü asırda Arap İslâm kültür ve edebiyatındaki gelişim devam ederek hicri dördüncü asır ve sonraki dönemlerde de gelişimini sürdürmüştür. Bu dönemde klasik birçok ülemâ ve üdebânın gayretiyle telif edilen belâğî ve edebî tenkîd konulu çalışmalar önemli bir yer edinmiş, tenkîd ile belâğat konuları arasındaki sağlam ilişkiden dolayı yaklaşık üç asır boyunca aralarında herhangi bir ayırım gözetmeksizin Ebû Ya'kūb es-Sekkâkî (öl. 626/1229) ve Hatîb elKazvînî’ye (öl. 739/1338) kadar iç içe işlenmiştir. ${ }^{27}$

Özellikle Abdulkâhir el-Cürcânî'nin Delâilu'l-i'câz' ve Esraru'l-Belâğa adlı eserlerinde fesâhatın ve güzelliğin sadece lâfız veya manâda olmadığını; bilâkis cümlenin nazmında ve cümleyi oluşturan unsurların arasında, başka bir deyişle cümle tekniğinde bulunduğunu ortaya koymasında etkilenen âlimlerinden biri de Usâma b. Münkız'dir. Kendisi el-Bedi' fî nakdi'ş-şi'r adlı eserinde bu yöntemi uygulamıştır. Üsâme b. Münkız tarafından ele alınan

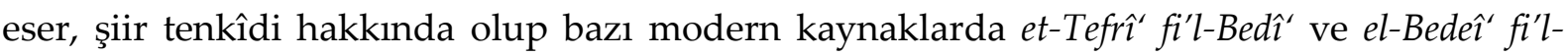
Bedî̀ gibi isimlerle kaydedilmekteyse de doğrusu el-Bedi' fî nakdi'ş-şi'r' $r^{\prime}$ dır. İlk olarak Abdu Ali Mihnâ tarafından Beyrut'ta 1987 yılında el-Bedề' fi'l-Bedî̀' ismiyle tahkik edilen eser, daha

\footnotetext{
26 'Abdulkâdir Hüseyn, el-Muhtasar fî târihi'l-belâğa (Kahire: Dâru'l-Ğarîb, 2001), 13-14; Mehmet Akif Özdoğan, “Belâgatın Sistematize Edilmesinde es-Sekkâkî ve el-Kazvînî'nin Rolü" Dinbilimleri Akademik Araştırma Dergisi 2/4 (2002), 99-100.

27 Hüseyn, el-Muhtasar fî târihi'l-belâğa, 11.
} 
sonra ise Ahmed Ahmed Bedevî ve Hâmid Abdulmecîd tarafından el-Bedi' fî naḳdi'ş-şi'r ismiyle neşredilmiştir. ${ }^{28}$ Müellif, eserin önsözünde gerek istifade ettiği kaynakları gerek eserin yazılış amacını ve gerekse nasıl bir yöntem izlediğini kendi ifadesiyle şöyle açıklamaktadır:

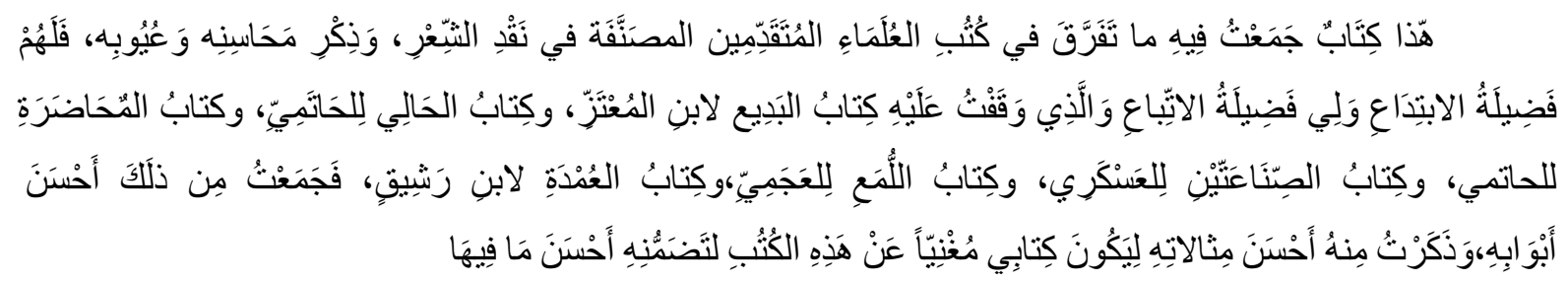

Eserin önsözünde de zikredildiği gibi yazar, kendinden önce kaleme alınan revaçta ve ünlü olan edebî tenkit kitapları tarayarak onlarda dağınık şekilde bulunan bilgileri derli toplu hale getirip okuyucuya sunmayı amaçladığı gibi, eserde şiirin güzel yanları ve kusurlarını da ele almaya çalışmıştır. Amaç onun bu eserini okuyanın, bu alanda artık diğer eserleri okuma ihtiyacı hissetmemesidir.

İbni'l-Mu’tezz, el-Hâtimî (öl. 388/998), Ebû Hilâl el-Askerî, el-Acemî’ ve İbn Reşîk elKayravânî gibi müelliflerin eserlerinden son derece faydalanmış ve bilgileri aldığı müelliflere de işaret ederek onları eserine referans olarak göstermeye çalışmıştır. Fakat bu kaynaklar arasında özellikle Ebû Hilâl el-Askerî'nin Kitâbü'ṣ-Sınâ'ateyn'i ve İ̉bn Reşîk'in el'Umde'sinden daha çok etkilendiği görülmektedir. Müellifin ismen zikrettiği bu altı kaynak ve müellif dışında tıbâk ve cinâs gibi sanatların taksimlerinden Aristoteles'in Poetika'sından, tenkit konusundan Ebû Bekir es-Sûlî́den (öl. 335/946) yanı sıra İbn Kuteybe, Kudâme b. Ca'fer (öl. 337/948), Sâhib b. Abbâd (öl. 385/995), Ebü’l-Alâ el-Maarrî (öl. 449/1057), Buhtürî ve Ebû Temmâm gibi edip ve çalışmalarından da etkilenmiş, dolaylı da olsa onları referans olarak göstermiştir. ${ }^{29}$ Şu bir gerçek ki, târihî seyri içerisinde birçok faktörden dolayı günümüze ulaşamayan ve zayi olan çok değerli eserler olduğu gibi Üsâme b. Münkız’ın da eserinde kendisinden faydalandığı bazı kaynaklar da maalesef çağımıza ulaşamamıştır. Dolayısıyla müellifin bu kaynaklardaki önemli ve seçici bilgileri eserinde kayıt altına alıp onların günümüze kadar kalıcı olmalarını sağlaması -"Söz uçar, yazı kalır.” atasözünde de ifade edildiği gibi- eserin değerini artırmaktadır.

28 İbn Münḳı, el-Bedi' fî nakdi'ş-şi'r, (mukaddime), 1-2; Ziriklî, el-A'lâm, 1/291; İbn Münḳ1z, Lübâbü'l-âdâb (mukaddime), 25-28; Dîvânü'ş-şi'r (mukaddime), 11; Sevim, “İbn Münḳız", 20/ 221-222.

29 Teysîr Recep en-Nesûr - Muhammed Ahmed Sevâliha, "Mesâdir Üsâme b. Münḳız, fi Kitâb'il-Bedi'”, Camiatu'l-Belka Dergisi, 593-611. 
Ebû Hilâl el-Askerî başta olmak üzere, ilgili alanda diğer ülemâ ve üdebânın da belâğat/retorik ve edebî tenkit hakkındaki tespit ve görüşlerini ele alıp değerlendiren ve onlardan farklı olarak edebî çalıntılar konusuna da yer veren dolayısıyla kendine ait bazı yenilikler ilave eden müellif, işlediği edebî sanat ve konuları bedî‘ başlığı altında doksan beş bâb altında sistematize ederek incelemeye çalışmıştır. Fakat eserde belâğat ilmi ile ilgili konular, modern dönem belâğat ilmi ile ilgili eserlerde olduğu şekliyle düzenlenmediği gibi belâğatın bütün konuları da ele alınmamıştır. Özellikle de konuları ve genel çerçevesi henüz tamamiyla belirlenmemiş olan semantik/meânî ilmiyle ilgili mevular daha az olduğu görülmektedir. Meânî ilmi ile ilgili isḥâb, iṭnâb, iḥtiṣâr, müsâvât, tezzyîl, tetmîm gibi konular ele alınırken, beyân ilmi ile ilgili ise istiâre, kinâye ve işâret gibi mevzular olup genel anlamda belâğatın beyân ilmi dalı ile ilgili konular incelenir.

Müellif, konuları açıklamada ve istişhâd konusunda izlediği yöntem ise bölümlerin her birinde konu hakkında âyet ve varsa hadisleri zikreder, daha sonra da seçkin kimselere ait şiir, atasözü, Arap kelâmı ve nesir gibi örneklerden de yararlanarak konuyu işlemeye çalışır. Örneğin müellif bedî‘ ilminin müḥassinât-ı lâfẓiyye /lafzi güzelleştiriciler sanatlarından biri olan ve tam cinâsı meydana getiren kelimelerin her ikisinin de isim, fiil ya da harf olma yönünden ortak olmaları anlamındaki cinâs-i mümâsili anlatırken şöyle der:

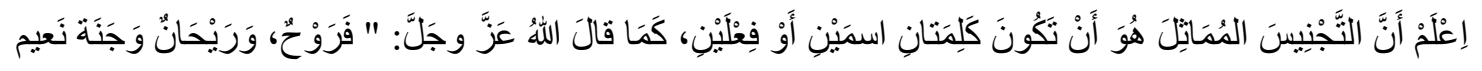

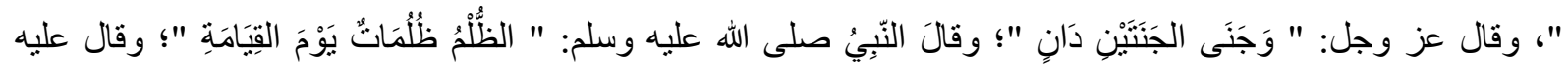

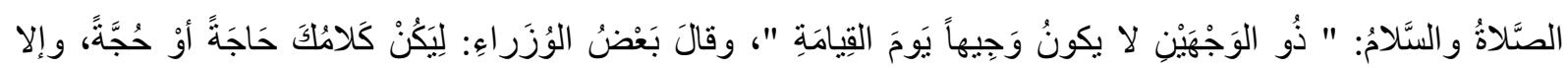

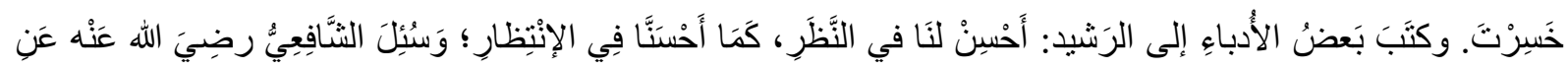

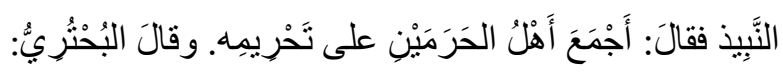

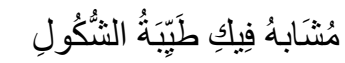
وَصَوْبُ المُزْنِ فِي رَاجِ شَشَولِ

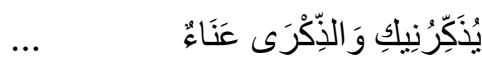

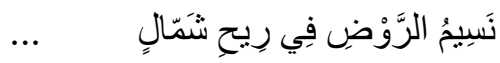

“Bilesin ki cinâs-i mümâsil, aynı cümlede bulunan iki kelimenin isim veya fiil olmasıdır. Yüce Allah'ın, “Ona huzur, güzel nasip ve nimetlerle dolu cennet vardır”30, “Bu iki cennetin de meyveleri kolayca erişilebilecek yakınlıktadır"31 âyet-i kerimelerinde ve Hz. Peygamberin, "Zulüm, kıyamet gününde zâlime zifiri karanlıklar olacaktır”, “İkiyüzlü insan kıyamet gününde önder olamaz" hadis-i şeriflerinde ifade ettikleri gibi (sesteş olan kelimeler ya isim ya da fiildirler.) Bazı vezirler, “sözlerin ya ihtiyaç duyulan bir şey veya senet/delil

30 el-Vâkı 56/89.

31 er-Rahmân 55/54. 
olsun, yoksa zarar etmiş olursun" derler. Bazı edebiyatçılar ise Hârûn er-Reşîd'e (öl. 786/809) şunu yazdılar: “İyi bir beklenti içerisinde olduğumuz gibi sen de (güzel hediyelerle) beklentimizi iyi karşıla". Ebû Abdillâh İdrîs eş-Şâfiî̀ye (öl. 204/820) - Allah ondan razı olsunnebizin /üzüm veya hurma suyundan mayalanmış sarhoşluk veren içkinin haram olup olmadığını soruldu. O da 'İki mükaddes yerin ehli, onun haram olduğu konusunda ittifak etmişlerdir", cevabını verdi. Buhtürî ise şöyle dedi: “Hatırlamak zor olsa da seni bana hatırlatıyor... Formunun güzelliğiyle sana benzemektedir. Kuzey rüzgârıyla esen bahçenin hoş esintisine ve şarap kokusu içinde bulutlarda çokça boşalan yağmura benzemektedir."32 Örnekte görüldüğü gibi müellif, mevzuyu kısa bir tanımdan sonra âyet, hadis, şiir ve Arap kelâmıyla temellendirmekte, genel anlamıla mevzuları açıklamada bu yöntemi ve siralamayı izlemektedir.

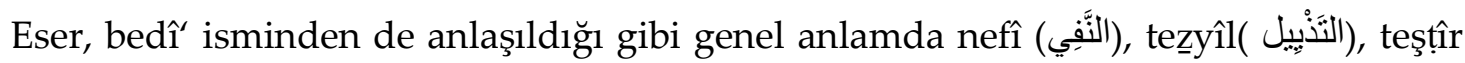

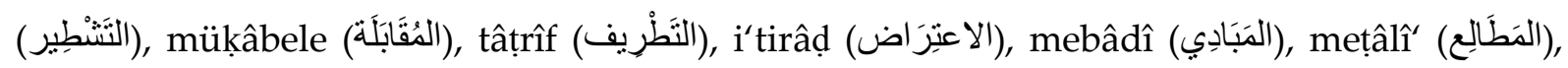
tahlîs (الخَرُْوج) gibi günümüz eğitim-öğretim edebî tenkit ve belâğat kitaplarında pek de karşılaşılmayan; ancak üslûbu güzelleştiren, ona âhenk katan ve bu alanda temel oluşturacak başlıklarla dolu olmasıdır. ${ }^{33}$ Esere önem kazandıran ve müellifin eserinde önem verdiği konulardan biri de es-Serikâtu'ş-şi' riyye (şiir hırsızlıkları), başka bir ifade ile edebî çalıntılara da değinmiş olmasıdır. Bu konuda birkaç fâsıl açarak; makbûl ve makbûl olmayan/ övünen ve yerilen edebî çalıntıları İbn Vekî̀ et-Tenîsî’den (öl. 393/1003) naklen on kısma ayrılarak açıklamaktadır. ${ }^{34}$ Müellif eserinde sadece üslûbu güzelleştiren ve ona renk katan bilgilerle yetinmeyip bilâkis haşv (الحَشو), galaṭ (الغَلَكَ), tefrît (التَفْرِيط), fesâd

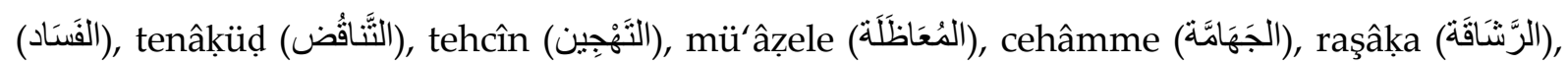

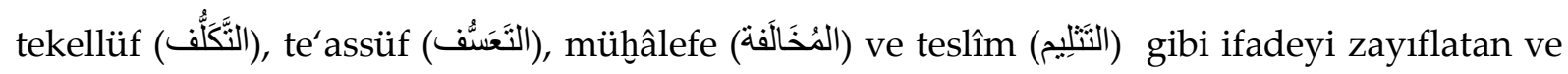

32 Üsâme b. Münḳız, el-Bedi' fî nakdi'ş-şi'r, 14-15.

33 Težyîl: Kelamda, önceki cümleyi teyid eden bir cümle getirme sanatıdır. Teşț̂r ve Mükâabele: Adından da anlaşıldığı gibi bir şiirde her iki mısradaki kelimelerin sayılarının aynı olmasıdır. Tâțrîf: Bir sözcüğün kendisinden önce gelen ya da onu izleyen kelimeyle sesteş, anlamdaş ya da aralarında herhangi bir bağlantı olduğunu ifade eden bir sanattır. İtirâḍ: Şiirin beytinde zaide/gereksiz olmayıp, aksine bir faydadan dolayı ara cümle zikretme sanatıdır. Mebâdî ve Mețâlı̂':Fesahat, belağat ve beyanın açık göstergesi olduğundan dolayı, nazım ve nesirde maksada ve muhtevaya işaret eden kelime ve deyimlerin yardımıla konuya ilgi çekici güzel bir üslûpla başlama sanatıdır. Tahlîs ve Huurûc: Klasik âlimlerinden çok modern ulemanın kullandığ bedî‘ $^{\prime}$ ilmine ait bir terim olup, edebî eserlerin güzel bir sözle bitirilmesini ifade eden bir sanattır. (Üsâme b. Münḳız, el-Bedi' fî nakdi'ş-şi'r, 8-299.)

34 Üsâme b. Münḳız, el-Bedi' fi nakdi'ş-şi'r, 182-191. 
değerini düşüren başlıklara da değinmektedir. ${ }^{35}$ Müellif bütün bunlara bir bâb (unvan) koyduktan sonra anlaşılır ve kolay bir üslupla tanımını yaparak gerek Kur'ân gerek hadis gerekse önemli miktarda seçkin şuarânın şiirleriyle ve füsehânın nesirleriyle konuyu açıklamaya çalışır. Bu anlamda eserde izlenen en açık yöntem, üslûbu güzelleştiren maddelerden sonra ifadeyi zayıflatan ve çirkinleştiren madde ve başlıkları ele alınmasıdır. Zira daha önceden de ifade edildiği gibi tenkit yani eleştiri, bir edebî ya da sanat eserinin başarılı ve zayıf, iyi ve kötü yanlarını belli bir takım bilimsel yöntemlerle incelenip onu ortaya koyulmasına denir. Ancak her şeyden önce - prensip olarak - yapıcı ve mantıklı tenkit/eleştiri, ele alınan şeyin olumlu- olumsuz, güzel- çirkin tarafı yanı sıra eksik ve aksaklıklarını birlikte ifade edilmeli ki tenkit daha verimli ve etkili olsun. Bir edebî eserin sadece kötü ve zayıf yanlarının sergilenmesi ya da sadece iyi ve güzel yanlarının ortaya konulması durumunda eleştiri yapılmış olamaz. Bu yönüyle eser, el-Bedi' fì nakdi'ş-şi'r (şiir eleştirisi/edebî tenkit konusunda eşsiz/benzersiz bir kaynak) unvanını hak ettiği rahatlıkla söylenilebilir.

Eserin son bölümünü şiir sanatı ve şâirin alet ve gereçlerine tahsis eden müellif, şiirin kısımlarından biri olan ta'lim ve tarsim ${ }^{36}$ başlığı altında şâirin güzel mânaları seçip güçlü ifadeler kullanması ve nazmın gereğine riayet etmesinin gerekliliği gibi bilgileri ele alır. Abdülkāhir el-Cürcânî'nin Delâilü'l-İ'câz adlı eserinde etkilenen müellifin, kalitenin sadece lâfız veya mânada olmadığını, ikisinin ruhla beden gibi birbirini tamamlamaları, dolayısıyla güzelliğin, fesahat ve belâğatın lâfız-mâna dengesinde başka bir deyişle lâfız-mâna

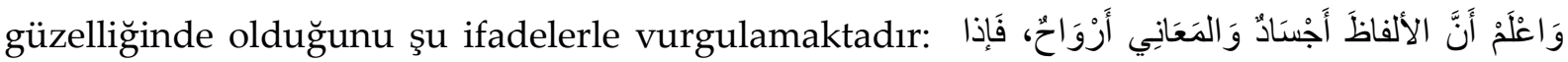
Bil ki! Kelimeler/ifadeler beden, mânalar ise ruh gibidir. Dolayısıyla lafızlar güçlü olunca manalar da sağlam olur/güçlenir."37

35 Haşv: Cümle içerisinde gereksiz ve herhangi bir faydası olmayan kelime veya kelimeleri kullanmayı ifade eden bir sanattır. Galaț: Gerek manayı gerek lafzı hatalı olarak kullanmak anlamında bir sanattır. Tefrîț: Yazarın ele aldığı konunun gerisinde kalmasını ve yeterli ölçüde olmamasını ifade eden bir sanattır. Tenâküụ: Şairin sözleriyle çelişmesini veya sözlerinin birbiriyle çeliştiğini ifade eden bir terimdir. Mü’âzele: Kelimeyi mana cihetiyle yanlış yerde kullanmasıdır. Cehâmme: Cümlede kulağa hoş gelmeyen ifadeleri kullanma anlamında bir sanattır. Tekellüf ve Te'assüf: Şairin bedi' ilmindeki tıbak ve cinas gibi sanatları kendini zorlayarak çok kullanmasını ifade etmektedirler. Mühâlefe: Şairlerin mezhebinden ayrılmak ve onları yol ve yordamını takip etme anlamında bir sanattır. (Üsâme b. Münḳız, el-Bedi' fî nakdi'ş-şi'r, 8-299.)

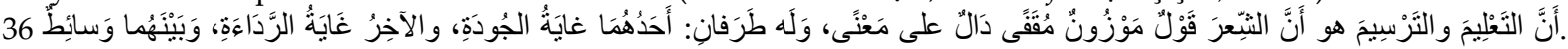
"Ta'lîm ve tarsîm, bir mânayı ifade eden vezinli ve kâfiyeli olup aralarında vâsıta/ilişki bulunan iki yönlü bir ifade demektir. Bir yönüyle son derece kaliteli iken diğer yönüyle son derece zayıftır." (Üsâme b. Münḳız, elBedi' fì nakdi'ş-şi'r, 289.)

37 Üsâme b. Münḳız, el-Bedi' fî nakdi'ş-şi'r, 294. 
Tehzîb ve tertîb ${ }^{38}$ bâbında ise şâirleri, şiirlerinin tashihine ve ince bir eleştiri süzgecinden geçirerek güzel bir şekilde kalıba dökülmesine çağırmaktadır. Bunu da şiirde, hece ve seslemlerin belirli miktarlarda tekrarlanmasıyla müzikal ve fonetik âhengi sağlayan kalıplar dizisi anlamındaki vezin kalıbının düzgün olması ve belli bir kıvama gelmesi için, nazma döktürdüğü sırada şiirini çokça tekrar etmesi ve onun içinde ifadeyi çirkinleştiren öğe ve lâfızları ayıklamasıyla başarabileceklerini önermektedir. Hattâ şiirin olgunlaşması ve tashihinin bol tekrara bağlı olduğu cihetiyle uzun bir zaman alabileceğini Hutay'e el-Absî (öl. 59/678) ve Züheyr b. Ebi Sülmâ (öl. 609 [?]) gibi şairlere ait olan şu anekdotları aktararak ifade etmeye çalışır:

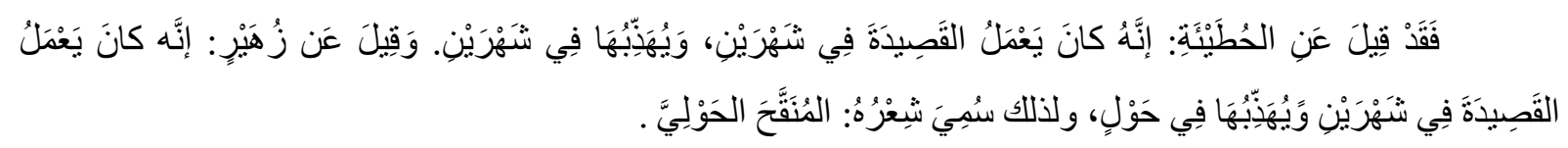

“Nitekim Hutay'e hakkında, kasideyi iki ayda yazar ve iki ayda da tashih ettiğini ve Züheyr hakkında ise şiirini iki ayda yazar ancak bir sene boyunca tashih edebildiğini bundan dolayı şiirleri el-münakkahiyyâtü'l-havliyye/yıllık tashihler olarak adlandırıldığı aktarılmaktadır." Ayrıca yazar devamında, şâirlere dikkat çekici önerilerde bulunup şiir sanatının inceliklerini sunmaya çalışarak vezin ve kâfiye aksaklıklarına rastlanmamaları için şiirlerinde kulağa tatlı gelen, dile ağır gelmeyen, kapalılıktan uzak, anlamı düzgün sözlerle kusursuz ve berrak bir dil kullanmaları, müktezây-1 hâle (ortama) göre sözü vecîz veya uzun tutmaları yanı sıra sağlam bir üslûba sahip olmaları gerektiğini de ifade etmektedir. Burada dikkat çekilen bir husus ise bitişin, başlangıç ile güzel bir uyum ve âhenk içerisinde olup hüsn-i ibtidâ ve hüsn-i intihâ sanatının gereğini yerine getirmeye dolaylı olarak işaret etmektedir. Hülasa müellif de hüsn-i ibtidâ ve hüsn-i intihâ sanatının gereğini yerine getirmek istemiş olmalı ki eserini gerek edebî tenkîd konusunda gerekse günlük hayatta istifade edilebilecek şu faydalı nasihat ve önerileriyle sonuçlandırarak şöyle der:

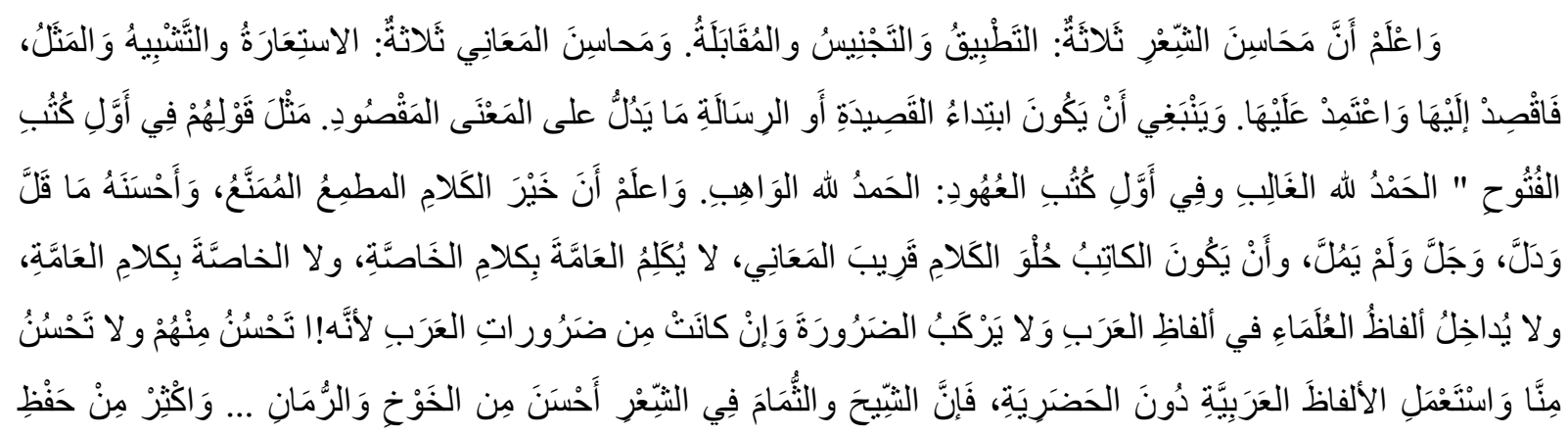

38 Tehzîb ve tertîb, lâfızlardan önce mânanın ve mısralardan önce ise kâfiyelerin oluşması demektir. (Üsâme b. Münḳı, el-Bedi' fí naḳdi'ş-şi'r, 295.) 


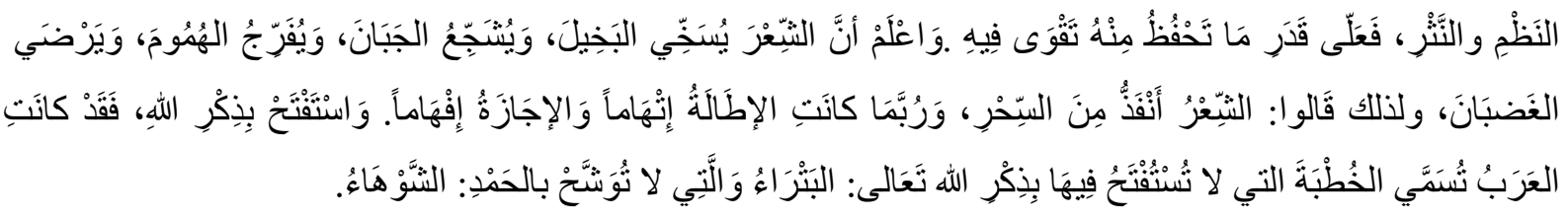

“Bilesin ki, şiirin güzellikleri tıbâk, cinâs ve mükâbele olduğu gibi mananın güzellikleri ise istiâre, teşbîh ve mesel şeklinde üç kısma ayrılmaktadır. Bunlara yönel ve dayan. Arapların, fetih kitaplarının başında gâlip olan Allah'a, sözleşme kitaplarının başında ise vehhâb olan Allah'a hamd olsun dedikleri gibi kasidenin/şiirin veya risalenin başlangıç cümlesi ana temayı içermesi/ona delalet etmesi gerekir. En hayırlı ve seçkin söz, muhatap onu işittiğinde benzerini yapmak istediği halde yapamadığı iken, en güzeli ise az sözle çok mâna ifade eden, yüce olup usandırmayandır. Yazar tatlı dilli olup anlamları anlaşılmaya/akletmeye yakın olmalıdır. Avâma/halka, sıradan insanlara havâsın ifadeleriyle ve havâsa da avâmın ifadeleriyle konuşmaz, hitap etmez. (Başka bir deyişle, kişinin seviyesine göre hitap etmeli ve ifadelerini kullanmalıdır.) Ulemânın sözlerini, Arapların sözlerine katmaz, onlarınmış gibi değerlendirmez. Araplardan gelmiş olsa da zarurete başvurmaz, zira zaruret onlara hoş gelse de bize hoş gelmez. Şehirlilerin değil, Arapların/füsehanın ifadelerini kullan. Nitekim fasih Arapların kullandıkları الثنَّام ve الثِيِّح ve (yavşan otu ve akdarı yaprağı) anlamındaki kelimeleri, şehirlilerin istimal ettiği الخَوْن ve الرُّمَانِ Gerek manzum/şiir gerek nesir alanında onları ezberleyebildiğin ölçüde güçlü olacağın için onları çokça ezberle. Bil ki şiir, cimriyi cömert yapar, korkağı cesaretlendirir, kaygıları giderir ve kızgın/öfkeli kişiyi ise teskin eder. Bundan dolayı Araplar, şiirin, sihirden daha etkileyici ve büyüleyici olduğunu ifade etmişlerdir. Nice uzun söz ve cümleler itham edilirken, vecîz olanı daha anlaşılır ve makbul olmuştur. Allah'ın adıyla başla. Nitekim Araplar, Allah'ın adıyla/besmele ile başlanmayan hutbeyi betra/kısır ve bereketsiz olarak adlandırılırken, hamdele ile süslenmeyeni ise şevha'/çirkin ve kusurlu olarak nitelendirmişlerdir." 39

Her sanat, eser ve çalışmanın övülen yanı olduğu gibi yerilen ve eleştirilen yanı olması da bilinen bir gerçektir. Bu anlamda el-Bedi' fì naḳdi'ş-şi'r adlı eserde edebî tenkîd ve bedî‘ konusunda genel anlamda müellif, seleflerinin görüşlerini aktarması cihetiyle eserin objektifliği ve özgünlüğü sınırlı olması, yazarın bazı edebî sanatların tanımlamamalarındaki eksikliği ve az da olsa döneminde güzel ve sevimli bulunmasına rağmen daha sonraki

39 Üsâme b. Münḳı, el-Bedi' fí nakdi'ş-şi'r, 295-299. 
dönemlerde hoş karşılaşılmayan bazı sanat ve ifadelerdeki abartı eserin yerilen, eksik ve eleştiren yanı olsa da ancak edebi tenkîd sahasında zengin bir literatür olması hasebiyle hepsini okumak, incelemek ve taramak uzun bir zaman alacağı muhakkaktır. ${ }^{40} \mathrm{Bu}$ bağlamda hassas bir dil zevkine sahip olan Usâma b. Münkız'ın eserinde bu sahada telif edilmiş, ekseriyeti temel kaynak olarak da nitelendirilen çalışmalardaki dağınık halde bulunan edebî tenkîd konusuyla ilgili bilgileri detaylı olmasa da derli toplu bir şekilde derleyip serd etmesi, eserin edebî tenkîd târihî sahasındaki yerini ve önemini korumakta, değerini artırmaktadır.

\section{Sonuç}

Şiirin Arap hayatındaki öneminden dolayı, iyi ve güzel olanın değerini ortaya çıkarıp kalitesizlikten kurtarmak, şiirle ilgili eseri kalıcı bir niteliğe kavuşturmak; şâiri de daha güzel yazmaya, onu olgunlaştırmaya ve daha başarılı eserler vermeye teşvik etmek, ona kılavuzluk yapmak gibi etkenler, şiir tenkidi gibi bir sanatın doğmasına vesile olmuştur. Şiir tenkidi ve belâğat ilmi aralarındaki sağlam ilişkiden dolayı birkaç asır boyunca edebî tenkit başlığı altında birlikte incelenmiştir. Daha sonra belâğat ilmi bağımsız bir hüviyet kazanınca, edebî tenkit daha çok şiir tenkidi için kullanılmış ve bu sahada birçok değerli eser yazılmış ve ciddi bir literatür oluşmuştur.

Bunlardan biri de Üsâme b. Münkız'ın el-Bedî̀ fî nakdi'ş-şi'r adlı eseridir. Eserde temel gaye, daha önce yazılmış bazı önemli çalışmaları inceleyerek edebî tenkit konusundaki bilgileri okuyucuya -detaylı olmasa da- derli toplu bir şey ortaya koymak ve sunmaktır. Bu bağlamda Ebû Hilâl el-Askerî'nin Kitâbü'ṣ-șinâ'ateyn'i başta olmak üzere İbni'l-Mu'tezz'in elBedî’si, el-Hâtimî'nin el-Hâll̂̀ ve' Hilyetü'l-muhâaḍara'sı, el-Acemî'nin el-Lüma'1 ve İbn Reşîk'in el- 'Umde'si gibi birçok kaynaktan yararlanmıştır. Bu gibi çalışmalarda dağınık halde bulunan gerek Arap belâgatı gerekse edebî tenkit konularının bir araya getirilerek belli bir plan ve yönteme göre taksim edilmiş olması; güzel ve zengin örnek seçimi eserin orijinal yönünü teşkil etmektedir.

Her ne kadar eser belâği/retorik nitelikte bir çalışma olsa da şiirin mısralarındaki güzelliği ve kusurları göstermekten geri kalmamıştır. Özellikle bu gibi konuları anlattıktan sonra edebî tenkit konusundaki bilgileri sunması, edebî çalışmanın kalitesi ancak bu sanatlardaki inceliklerle anlaşılabileceğine dikkat çekmektedir. Dolayısıyla târihî seyri içerisinde edebî tenkit sahasında günümüze ulaşmayı başarabilmiş, daha sonraki bazı

40 Muhammed Abdülmuttalib, İtticâhâtu'n-nakd hilâle karni's-sâdis ve's-sâbi' el-hicrî (b.y. Dâru'l-Endülüs, 1984), 30. 
çalışmalara kaynaklık etmiş ve vecîz yönüyle alanında kendisinden istifade edilebilecek önemli bir eser hüviyeti kazanmıştır. 


\section{Kaynakça}

Abdülmuttalib, Muhammed. İtticâhâtu'n-Naḳd Hilâle Karni's-Sâdis ve's-Sâbi' el-Hicrî. b.y.: Dâru'1-Endülüs, 1984.

Asmaî, Ebû Saîd Abdülmelik b. Kureyb el-Bâhilî, Kitâbu fuhûleti'ş-şu'arâ. thk. Charles C. Torrey, Yay. Haz. Selâhuddîn el-Müncid. Beyrut: Dâru'l-Kutub'il-Cedîd, 1400/1980.

Bulut, Ali. Belâgat (Meân̂̀ - Beyân - Bedî'). İstanbul: M. Ü. İlahiyat Fakültesi Yayınları, 4. Basim, 1433/2015.

Corcî Zeydân, b. Habîb. Târîhu âdâbi'l-luggati'l- 'Arabiyye. 4 Cilt. Kahire: Dâru'l-Hilâl, ts.

Çetin, Nihat M. Eski Arap Şiiri. İstanbul: Edebiyat Fakültesi Yayınları, 1973.

Demirayak, Kenan - Çöğenli, M. Sadi. Arap Edebiyatında Kaynaklar. Erzurum: Atatürk Üniversitesi Fen Edebiyat Fakültesi Yayınları, 2000.

Demirayak, Kenan. Arap İslam Edebiyatı Literatür Bilgisi. İstanbul: Cantaş Yayınları, 2016.

Durmuş, İsmail. "Sa'leb". Türkiye Diyanet Vakfı İslam Ansiklopedisi. 25-27. İstanbul: Türkiye Diyanet Vakfı Yayınları, 2009.

Ekinci, İsmail. “Arap Şiiri Ansiklopedisi Programı (el-Mevsû'atu'ş-Şi'riyye)”. Marife Dini Araştırmalar Dergisi 19/2 (2019), 768-769.

Er, Rahmi. “Tenkit”. Türkiye Diyanet Vakfı İslam Ansiklopedisi. 40/458-461. İstanbul: Türkiye Diyanet Vakfı Yayınları, 2021.

Feyyûmî, Ebü'l-Abbâs Hatîbüddehşe Ahmed b. Muhammed b. Alî el-Hamevî. el-Miṣbâhu'lmünîr fì garî̉bi'ş-şerhi'l-kebîr li'r-Râfi î̀. 2 Cilt. Kahire: y.y. 1325/1901.

Fîrûzâbâdî, Ebü't-Tâhir Mecdüddîn Muhammed b. Ya'kūb b. Muhammed. el-Kāmûsü'lmuhîț. Beyrut: Müessisetü'r-Risale Li't-Tiba' ve'n-Neşr, 8. Basım 1426/2005.

Güceyüz, İsa. "Belâgat ve Edebî Tenkit Terimlerinin Teşekkülü Üzerine Bir Bibliyografya Denemesi I". Hitit Üniversitesi İlahiyat Fakültesi Dergisi 19/1 (2020), 477-508.

Hüseyn, Abdulkâdir. el-Muhtașar fî târihi'l-belâğa. Kahire: Dâru'l-Ğarîb, 2001.

İbn Hallikân, Ebu'l-Abbâs Şemsuddîn Ahmed b. Muhammed el-İrbilî. Vefeyâtu'l-a'yân ve enbâu ebnâi'z-zamân. thk. İhsân Abbâs. 8 Cilt. Beyrut: Dâru Sadır, 1398/1978.

İbn Reşîk el-Kayrevânî, Ebû Alî el-Hasen el-Ezdî el-Mesîlî. el- 'Umde fî mehâsinini'ş-şi 'r ve âdâbih ve naḳdih. thk. en-Nebevî Abdulvâhid Ş‘lân. 2 Cilt. Kahire: Mektebetü'l-Hancî, $1420 / 2000$.

İbnü'l-'İmâd, Ebu'l-Felâh Abdulhayy b. Ahmed b. Muhammed es-Sâlibî el-Hanbelî edDimeşkî. Şežerâtü'z-žeheb. thk. Abdulkâdir el-Arnâvud - Mahmûd el-Arnâvud. 10 Cilt. Beyrut: Dâru İbn Kesîr, 1406/1986.

İbnü'l-Manzûr, Ebü'l-Fazl Cemâlüddîn Muhammed b. Mükerrem b. Alî b. Ahmed el-Ensârî er-Rüveyfiî. Lisânu'l-'Arab. 15 Cilt. Beyrut: Dâru Sâdr, 3. Basım, 1414.

İbnü'l-Mu'tezz. Ebü'l-Abbâs Abdullāh b. Muhammed b. Ca'fer el-Mütevekkil-Alellah elAbbâsî. Kitâbu'l-Bedî’. thk. İrfân Matracî. Beyrut: Müessisetü'l-Kutubi's-Sakafiyye, 2012.

İbnü's-Sellâm el-Cumahî, Ebû Abdillâh Muhammed b. Ubeydillâh b. Sâlim el-Basrî. Tabakātü fuḥ̂̂li'ş-şu 'arâ'. nşr. M. M. Şâkir. Kahire: y.y. 2. Basım, 1980/1400.

Kudâme b. Ca'fer, Ebü'l-Ferec b. Kudâme b. Ziyâd el-Kâtib el-Bağdâdî. Nakdü'ş-şi $r$. thk. Muhammed Abdülmün'im Hafâcî. Beyrut: Dâru'l-Kutubi'l-illmiyye, ts.

Lüğavî, Ebü't-Tayyib Abdülvâhid b. Alî. Merâtibü'n-nahviyyîn. nşr. Ebü'l-Fazl İbrâhim. Kahire: Dâru'1-Maârif, 1375/1955.

Nesûr, Teysîr Recep - Sevâliha, Muhammed Ahmed. “Mesâdir Üsâme b. Münkız fi Kitab'ilBedi'". Camiatu'l-Belka Dergisi. 593-611. 
Ömer Ferrûh, Ömer Abdirrahmân. Târîhu'l-edebi'l- 'Arabî. Beyrut: Dâru'l-i̇lmi li'l-Melâyîn, 4. Basım, 1981.

Özaydın, Abdulkerim. "Münkız/Benî Münkız", Diyanet İslam Ansiklopedisi. 32 / 15-16. İstanbul: Türkiye Diyanet Vakfı Yayınları, 2006.

Özdoğan, M. Akif. "Belâgatın Sistematize Edilmesinde es-Sekkâkî ve el-Kazvînî’nin Rolü”. Dinbilimleri Akademik Araştırma Dergisi 2/4 (2002), 98-106.

Özdoğan, M. Akif. “Klasik Arap Edebî Tenkidine Genel Bir Bakış”. Kahramanmaraş Sütçü İmam Üniversitesi Sosyal Bilimler Dergisi 12/ 1 (2015), 1-28.

Sa'leb, Ebü'l-Abbâs Ahmed b. Yahyâ b. Zeyd b. Yesâr (Seyyâr) eş-Şeybânî. Kava'idu'ş-şi'ir. thk. Ramazan Abduttevvâb. Kahire: Mektebetu Hâncî, 2. Basım, 1375/1995.

Safedî, Ebu's-Safâ Selâhuddîn Halil b. İzziddîn Aybeg b. Abdillâh. el-Vâfî bi'l-Vefeyât. thk. Ahmed el-Arnâvûd; Tûkî Mustafâ. 29. Cilt. Beyrut: Dâru İhyâi't-Turâsi'l-Arabî, 1420/2000.

Sevdi, Ali. Arap Grameri Literatüründe Sa`leb ve el-Mecâlis'i. Erzurum: Atatürk Üniversitesi, Sosyal Bilimler Enstitüsü, Doktora Tezi, 2019.

Sevim, Ali. "İbn Münkız", Diyanet İslam Ansiklopedisi. 20/ 221-222. İstanbul: Türkiye Diyanet Vakfı Yayınları, 1999.

Üsame b. Münkız, Ebü'l-Haris Müeyyidüddevle Necmüddîn b. Mürşid b. All b. Mukalled b. Nasr eş-Şeyzerî el-Kinanî el-Kelbî. el-Bedi' fì naḳdi'ş-şi’r. thk. Ahmed Ahmed Bedevî Hâmid Abdulmecîd. Kahire: y.y. 1380/1960 - Beyrut: y.y. 1407/1987.

Üsame b. Münḳı, Ebü'l-Haris Müeyyidüddevle Necmüddîn b. Mürşid b. All b. Mukalled b. Nasr eş-Şeyzerî el-Kinanî el-Kelbî. Lübâbü'l-âdâb. thk. Ahmed Muhammed Şâkir. Kahire: Mektebetü's-Sünne, 1408/1987.

Üsame b. Münḳı, Ebü'l-Haris Müeyyidüddevle Necmüddîn b. Mürşid b. All b. Mukalled b. Nasr eş-Şeyzerî el-Kinanî el-Kelbî. Dîvânü'ş-şi'r, thk. Ahmed Muhammed Bedevî Hâmid Abdülmecîd. Kahire: Âlemü'l-Kutub, 1983.

Üsame b. Münḳı, Ebü'l-Haris Müeyyidüddevle Necmüddîn b. Mürşid b. All b. Mukalled b. Nasr eş-Şeyzerî el-Kinanî el-Kelbî. Kitâbu'l-I'tibâr. thk. Abdulkerîm el-Eşter. Beyrut: Mektebetü'l-İslâmiyye, 1424/2003.

Yâfiî, Ebû Muhammed Abdullâh b. Esâd b. Ali b. Süleymân el-Yemenî. Mir'âtü'l-cenân ve 'ibretü'l-yakzânn fi ma'rifeti havâadisi'z-zamân. 4. Cilt. Beyrut: Dâru Kutubi'l-îlmiyye, 1417/1997.

Yâkūt el-Hamevî, Ebû Abdillâh Şihâbüddîn b. Abdillâh el-Bağdâdî er-Rûmî, Mu'cemü'lüdebâ'. thk. Hasân Abbâs. 7. Cilt. Beyrut: Dâru'1-Ğarbi'l-İslâmî, 1993.

Yıldız, Hakkı Dursun. "Abbâsîler", Türkiye Diyanet Vakfı İslam Ansiklopedisi. 1/31-48. İstanbul: Türkiye Diyanet Vakfı Yayınları, 1988.

Ziriklî, Ebû Kays Muhammed Hayruddîn b. Muhammed b. Ali b. Fâris ed-Dımeşkî. el-A'lâm. 8. Cilt. Beyrut: Dâru 'İlmi li'l-Melâyîn, 15. Basım, 1984. 